\title{
Chapter 13 \\ Making Sense of Segregation in a Well-Connected City: The Case of Berlin
}

\author{
Talja Blokland and Robert Vief
}

\begin{abstract}
This chapter analyses socioeconomic segregation and segregation by migration background for Berlin, Germany. Berlin's history of division and reunification affected suburbanization patterns and the unequal economic restructuring of the city over time. Within this historical context, we present our empirical results on segregation, and we reflect on the implications of segregation for the daily use of the city. Arguments that segregation affects access to amenities (as in the literature on 'food deserts') or reduces access to jobs (as in spatial mismatch theories) are not so useful for Berlin with its strong public transport infrastructure. We find that socioeconomic segregation was moderate and stable for the working-age population between 2007 and 2016, whereas segregation of poor children increased. At the same time, segregation of foreigners and segregation by migration background strongly declined. And yet, even though segregation levels are low and public services are present everywhere, the social use of the city, we argue, may be more segregated than statistical indicators suggest. Drawing on various case studies, we suggest that the use of the overall city reflects segregation patterns of the use of space for other reasons than commonly suggested.
\end{abstract}

Keywords Residential segregation $\cdot$ Social segregation $\cdot$ Berlin $\cdot$ Child poverty $\cdot$ Resource access

\footnotetext{
T. Blokland $\cdot$ R. Vief $(\bowtie)$

Department for Urban and Regional Sociology, Institute of Social Sciences, Humboldt-Universität Zu Berlin, Berlin, Germany

e-mail: robert.vief@hu-berlin.de

T. Blokland

e-mail: talja.blokland@ sowi.hu-berlin.de
} 


\subsection{Introduction}

Residential segregation means that people put in a box of statistical similarity (socioeconomic or racially/ethnically constructed categories) live closer to people in that same box than to others. Living is measured in most segregation studies by where one is registered. In most cases, that is where we sleep.

Policymakers and politicians see segregation as problematic for roughly three sets of reasons. First, segregation can reinforce inequalities if it constitutes differential access to urban amenities, as discussions of, for example, 'food deserts' and spatial mismatch in the labour market suggest (Holzer 1991; Wrigley 2002). Especially in non-European cities, the presence and quality of formal amenities connect directly to segregation patterns (Marques 2012). Second, whether from a perspective of containment and punishment of the poor in the hyper-ghetto (Wacquant 2008), or conservative versions of the culture of poverty thesis (Herrnstein and Murray 1996), segregation discussion may include cultural worries (Sampson 2012; Gould 1999): isolation reduces connection to mainstream values, with various ascribed negative consequences. Third, worries about segregation premise that negative consequences occur as neighbourhood effects. Living among others with similar limitations, so the argument goes, would further limit chances to get ahead (Souza Briggs 1997), or hamper collective efficacy (Sampson et al. 1997). In European cities especially, segregation of income groups correlates with segregation of people without and with (recent) migration histories or 'ethnic minorities', which is a result of specific racialized logics of capitalism and colonialism and thus of global inequalities. Many European public discussions thus express worries about segregation not simply because of poor people's isolation. Instead, these discussions at times disguise a cultural-racist debate when labels of disadvantaged neighbourhoods or concentration areas point to where the poor live in higher densities but primarily draw attention to ethnic minority concentration.

All these approaches share the assumption that where we sleep has high relevance for our lives. This seems obvious in a favela where the bus may only come twice a day (or not at all). It may even apply to Chicago (but not New York; Small 2009). But what does residential segregation mean in a well-connected and not-so-huge city? Do residential segregation patterns matter? What for?

Berlin, as a medium-sized city with a well-functioning public transport system and infrastructure, serves as a case to reflect on these questions. Its history as a divided city makes it an exceptional case, provoking questioning of some standard segregation arguments. This chapter aims to explore whether Berlin has segregation patterns at all, how these patterns may have developed over time, and how to interpret them. We first discuss the German and Berlin historical context. After describing Berlin's data-shortage and our analytic choices, we analyse indicators for socioeconomic and migrant segregation. Finally, we connect statistical findings to city use as a daily routine, pleading for more focus on social rather than residential segregation. 


\subsection{From Divided to Gentrified City}

Germany's socioeconomic inequality, measured by the GINI index (G), decreased from 1990 to 1998 and increased from 1998 to 2005 (28.3 in 1998 to 32.3 in 2005). ${ }^{1}$ Scholars using different data acquire different results, but sketch a similar trend of strongly increasing inequality from the 1990s to 2005. Since then, World Bank data suggest a drop in income inequality from 2005 to 2010 (32.3 to 30.2) and an increase until 2015 (31.7). Although the GINI coefficient cannot be reported for all years of our analysis for lack of data $(2007,2012,2016$ - see methods section below), the trend lagged by one year shows a slight U-shape (2006: 31.3; 2011: 30.5; 2015: 31.7). Most statistical offices also computed a minor drop after 2005 but underline a mostly stable situation from 2005 to 2016, around a GINI coefficient of 0.29 (Grabka et al. 2019). In contrast, some researchers emphasize that affluent households profited most from wage increases over the last twenty years, while in the lowest deciles of the income distribution, hardship remained. Income inequality since 2010 sharpened, especially in major cities in Germany, where low-income households have become disproportionally numerous (ibid.). Berlin's statistical office highlights an increase of the GINI coefficient until 2003 and stability since then (Amt für Statistik Berlin-Brandenburg 2017a: 48), showing a very similar stable pattern for our period of interest as for Germany overall $(\mathrm{G}=30.0$ for 2006, 2011 and 2015). Berlin's Bezirke (12 districts of around 300.000 inhabitants) have higher income inequality in the West than in the East. East Berlin's Lichtenberg $(G=23)$ or Marzahn-Hellersdorf $(G=25)$ have much lower levels of income inequality than for example Charlottenburg-Wilmersdorf ( $\mathrm{G}$ $=35$ ) in the West (ibid.: 49). This inequality, and forms of segregation connected to it, must be understood in Berlin's peculiar context.

After the Second World War, Soviet Union, France, UK and USA divided Germany into two: German Democratic Republic (GDR) and Federal Republic of Germany (FRG). Berlin, as capital, was divided into four sectors, one in East (under Soviet control) and three in West Berlin (under control of France, UK and USA). Soon, the tension between the USSR communist project in East Berlin and the predominantly USA project of market capitalism in West Berlin created a peculiar situation for residents. The breaking up of Germany (and Berlin) was an imposed political project against its unity, not a fortification of a boundary that in any sense was lived-ideologically, religiously, or else-by people or their movements. Notwithstanding regional differences, nation-state building since the late nineteenth century had worked effectively towards the creation of German unity. Berlin's division thus resulted not, as former divided cities like Belfast or Mostar, from activation of symbolic boundaries of ethnicity, religion or both. Figure 13.1 shows Berlin's current Bezirke and the Wall's location.

Of all Germans, Berliners experienced the artificiality of the divided life most extremely. With the construction of the Berlin Wall in 1961, places and people in the daily lives of Berlin residents were suddenly separated. To understand contemporary Berlin, this division matters in various ways. First, the building and then the removal

\footnotetext{
${ }^{1}$ https://data.worldbank.org/indicator/SI.POV.GINI?locations=DE.
} 


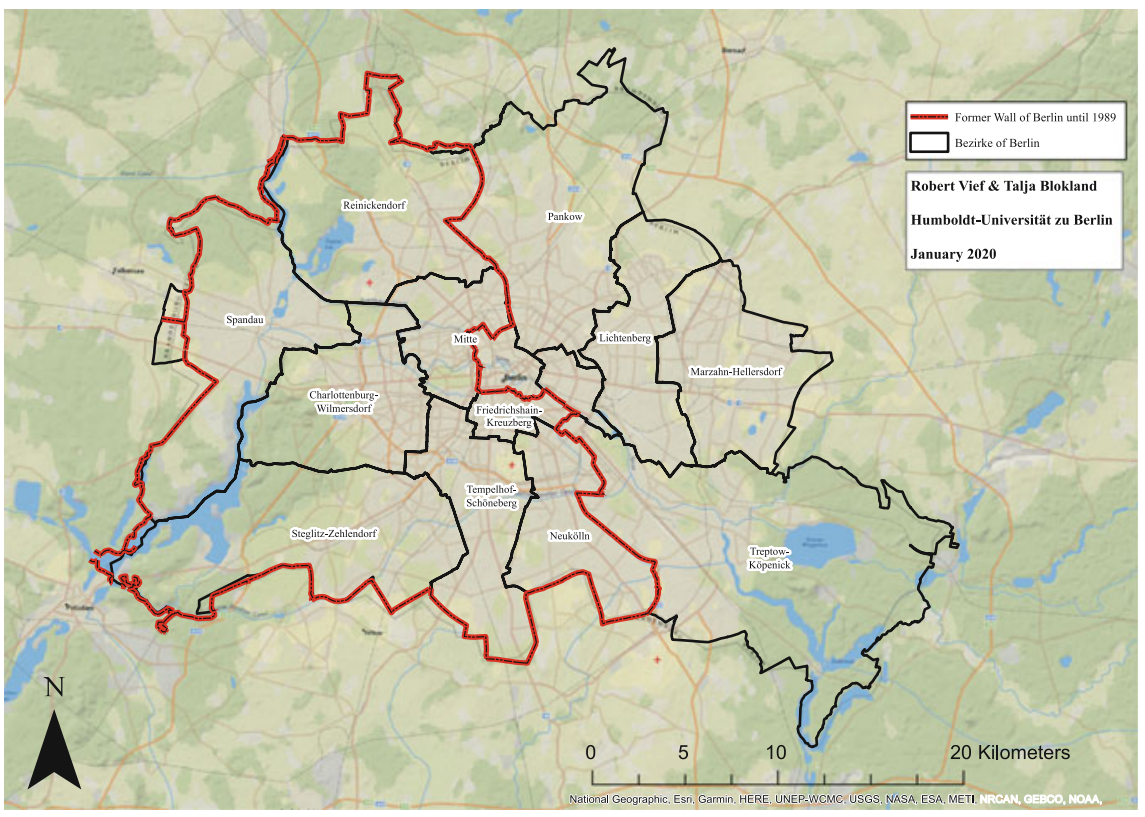

Fig. 13.1 Berlin's Bezirke (today) and the Wall until 1989

of the Wall through the city's (war-damaged) heart moved the city's core. Today's central sites used to be dead-end streets facing the Wall, which had a ca. 100-mwide 'Dead Strip' on the East. This vacant land strip was a waiting opportunity for developers in the 1990s (Fig. 13.2).

GDR politics of a classless society favoured massive apartment constructions, especially in Lichtenberg and Marzahn-Hellersdorf, while ignoring, for example, Prenzlauer Berg with its bourgeois housing. Low levels of maintenance and investment (Dahn 1987: 39 in Häußermann and Kapphan 2002: 71) caused major housing deterioration. People living there were denied access to the new higher-quality apartment blocks for lack of state compliance, voluntarily distanced themselves from the state, or temporarily waited there for better housing (ibid.). In the 1990s, these dilapidated buildings with desirable 1800s Altbau designs provided excellent investment opportunities. After the fall of the Berlin Wall (the Wende in 1989), the area near the Wall, which for decades was two cities' edge, became a central district with high-quality amenities, international schools, bilingual kindergartens, yoga-classes for toddlers, etcetera. Especially since the early 2000s, the central city attracted a middle class and saw its public and private service sector changing tremendously.

Third, politics of representation in West and East Berlin before the Wende had created two divergent urban landscapes (see Häußermann and Kapphan 2002: 624). After the Wende, a quick expansion and integration of infrastructures and public transport in what was to become the capital of reunited Germany became politically urgent. The move of the federal parliament's seat and most West-German government 


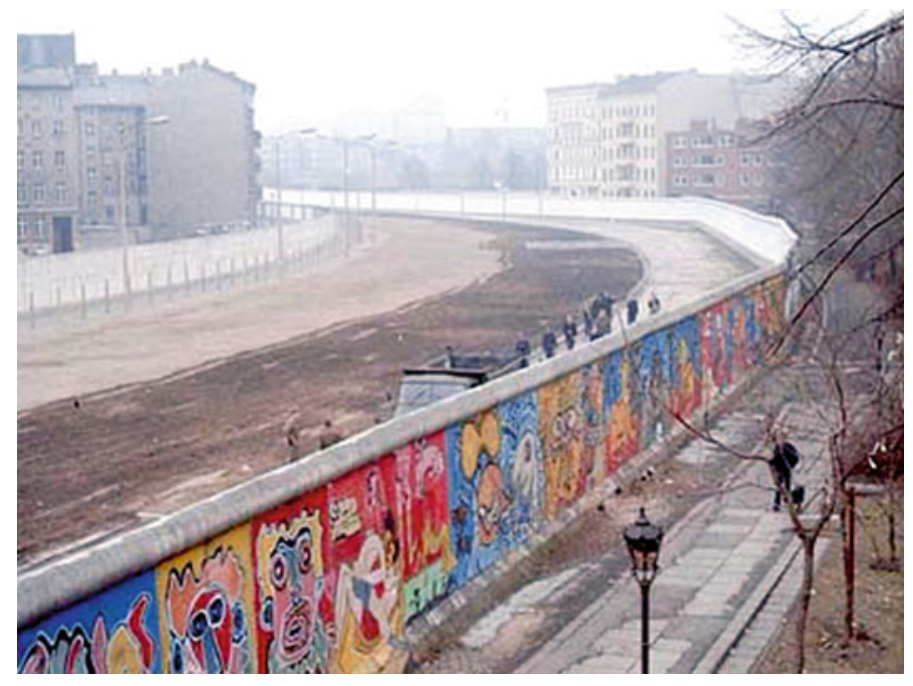

Fig. 13.2 Berlin Wall, 1986. Source https://en.wikipedia.org/wiki/File:Berlinermauer.jpg, by user: Noir/WikiCommons, 22-Mar-2004, GNU free under a CC BY-SA-3.0 Unported license. Photographer Thierry Noir/Bethaniendamm, Berlin-Kreuzberg, Germany, 1986

institutions from Bonn to Berlin in 1991 strengthened this process (Kemper 1998b: 1766). Political choices in housing policies since the unification (see Bodnar and Molnar 2010) produced a housing system dominated by private rental apartments. Homeownership remained hard to realize within the city. Especially the privatisation of GDR state-owned areas where rents had been fixed at very low rates before reunification produced an exception to common understandings about housing markets. Privatisation of public housing to reduce the city's financial problems and restitution of buildings collectivized under communism to previous owners, also impacted the rental market. In short, Berlin's contemporary housing situation results from a combination of investments of second circuit international capital (Harvey 1978) at a historical moment of an ideological belief in the superiority of market capitalism, a need to increase state revenue because of the historically conditioned need for public investment, and unprecedented freedom of residential choice. Berlin's gentrification - the increase of middle and upper-class residents displacing lower-income residents-occurred in this context.

Meanwhile, the Wall's disappearance made suburbanization possible overnight, causing a sharp population-decline in 1990s Berlin (Beyer and Schulz 2001: 123 quoted in Kirchner 2009). In Germany's specific suburbanization trajectory (Matthiesen and Nuissl 2002), Berlin was even more specific (Bluth 2004). In pre1989 East Berlin, limited possibilities of homeownership and strict state-led distribution of rental dwellings had prevented market-led suburbanization. In West Berlin, the Wall had prevented all outward expansion. Berlin's population dropped between 1990 and 2004 while surrounding Brandenburg saw a sharp population increase 
(Beran et al. 2015). For example, Falkensee, bordering directly at West Berlin's Spandau, grew in a decade from 22,087 to 40,511 residents, causing challenges to cohesion, identity and infrastructure (Kirchner 2009: 41f). Since 2004, more people move from Berlin to Brandenburg than in the other direction (Beran et al. 2015). And yet, the influx from other German states and abroad made Berlin grow from 3.3 to 3.75 million between 2004 and 2018 (Amt für Statistik Berlin-Brandenburg 2019).

Both in the East and the West before the Wende, industries received politically motivated state-support. As this disappeared after the Wende, deindustrialisation followed, especially but not exclusively in the East, causing high unemployment rates and the lowest GDP of all European metropoles compared to their nationwide averages (Bernt et al. 2013: 16; Gornig et al. 2013: 8f). In the early 2000s, sociologists predicted growing economic marginalization (Kronauer 1997 in Häußermann and Kapphan 2002: 18). Instead, in the last decade, Berlin grew economically, land values increased, and unemployment rates declined. This decrease in unemployment partly results from growth in flexible service-jobs with little income security. In East Berlin, pre-1989 full employment with absolute job security and low income and little consumer goods availability has now turned into low unemployment but high job insecurity, continuous low or moderate incomes, rent increase and endless consumer goods - unaffordable for many. Additionally, younger and new Berliners face precarity in self-employment in the creative sector. ${ }^{2}$

Berlin has moved from a politically divided city to a city with new divisions. It undergoes well-documented gentrification (Holm 2013), to which political initiatives seek answers, including housing development in selected surrounding Brandenburg areas, which will further affect its demography. But Berlin also moved from a city initially divided only by political decision to a city of distinctive social lives. We explore what segregation may mean in this context after presenting Berlin's statistical development of segregation.

\subsection{Methods}

German scholars and journalists vigorously debate segregation but lack precise, small-scale data to demonstrate the existence of poverty pockets before 1998 (Kemper 1998a: 22) and have limited data since then. Some described a stable rate of socioeconomic segregation between 1990 and 2005 for Berlin (Friedrichs and Triemer 2009: 120), but only based on analysis of large spatial units (ibid.: 20) or argued that in the 1990s, poverty increasingly concentrated in specific neighbourhoods (Häußermann and Kapphan 2004) and produced social problems, but again drawing on limited

\footnotetext{
${ }^{2}$ Figures suggest weak correlations between education and income for residents without migration background or European Union backgrounds (especially Italy, Spain, Greece since 2008s crisis) (Gathmann et al. 2014).
} 
data. Others found that social segregation by Sozialgesetzbuch $\mathrm{II}^{3}$ slightly increased between 2005 and 2014 (Helbig and Jähnen 2018: 139).

Germany has poor statistics. Before 1989, the FRG and the GDR had their own ways of collecting census data. After reunification, Germany delayed the census to 2011, leaving a 24 year gap (Statistische Ämter des Bundes und der Länder 2015: 9). Berlin does not have a useful panel of census data since 1989. Germany does not collect census data on income. It does not publish data on occupational status for cities (which it collects; Eisenmenger et al. 2014; Heckel and Heyde 2015). On the local level, census data regulations are stricter than in other countries. The Mikrozensus, Germany's largest household survey, allows predictions of income distributions but does not publish data for spatial units smaller than Berlin's 12 Bezirke. The spatial sampling of the Mikrozensus is on the same scale, so we cannot infer to smaller levels.

Berlin answered in 2006 to the lack of data with the Monitoring Soziale Stadtentwicklung, an initiative of academics and city planners to join available data sources on a low spatial scale to assess neighbourhoods' relative positions. The LORs (Lebensweltlich-Orientierte Räume) in the Monitoring provide 447 spatial units (Planungsräume) with 7,500-10,000 inhabitants (Bömermann et al. 2006). ${ }^{4}$ The data do not include income. Fortunately, income is only one indicator suggesting where the rich, the poor and others live. As proxies for economic status, the Monitor contains information on unemployment, state family subsidies and child poverty.

We analyse data for three time points $(2007,2012,2016)$ with four indicators of socioeconomic segregation: unemployed persons among people aged 15-65; longterm $^{5}$ unemployed persons among those aged 15-65; non-unemployed recipients of state subsidies in all age groups (for example when people work but make too little to reach the minimum state-guaranteed standard, receive very low pensions, or have children living in a poor household); and poverty among children aged $0-15$. These indicators allow an estimation of the lower part of the income distribution. They cannot show polarization of the rich within neighbourhoods and throughout Berlin.

Scholars have also investigated 'ethnic' segregation of legally defined foreigners in neighbourhoods. Kemper (1998a, b) found ethnic segregation to be stable during the 1990s in West Berlin and to decline in East Berlin until 1996. Overall, ethnic segregation rates were higher in East Berlin, where residential mobility was very low. Friedrichs and Triemer (2009: 120f) observed an increasing level of segregation until the mid-2010s. Helbig and Jähnen (2018) observed a decrease since 2002. Again, both used data on a high spatial scale. Häußermann and Kapphan (2002: 212) underlined the increasing concentration of foreign-born residents since the 1970s (with only 20,000 foreigners in entire East Berlin), then stability since the 1990s, but on Bezirke scale. Existing studies thus do not report consistent results and use different spatial scales-we aim to clarify the recent development on a small spatial scale.

\footnotetext{
${ }^{3}$ Sozialgesetzbuch II only covers a part of the unemployed population.

${ }^{4}$ We exclude 14 LOR-Planungsräume with fewer than 300 inhabitants in our analyses.

${ }^{5}$ Unemployed over one year without interruption, Sozialgesetzbuch II and III (Nagel 2018: 16f).
} 
Germany collects no data of racialized categories, but we can compute segregation of foreigners and Germans with a migration background, also clustered by country -of -origin groups. We analyse such segregation using proportions of foreigners and persons with a migration background, ${ }^{6}$ and by country groups (European Union and Turkey/Muslim States). ${ }^{7}$ We are aware of the ways in which statistics construct categories: as our last section will show, for Berlin's social landscape, or how the city is lived and used, these social constructions and their imaginations matter: stereotyping people with certain passports as 'Muslim' is an act of othering.

We calculated residential segregation using the segregation index (IS) ${ }^{8}$ and the location quotient (LQ) with the Geo-Segregation Analyzer (Apparicio et al. 2013). We cannot report indices of dissimilarity between groups of our analysis, because the groups partly overlap (long-term unemployed residents count also as unemployed; poor children may also be residents receiving subsidies, etc.).

\subsection{Socioeconomic Segregation}

Figure 13.3 shows the IS for 3 years of data for socioeconomic and ethnic indicators: Berlin's moderate unemployment and long-term unemployment segregation was stable between 2007 and 2016, with a tiny drop between 2007 and 2012. Poor children and state support recipients became slightly more segregated over time, especially between 2007 and 2012. Poor children lived overall much more segregated than other categories (IS .43/42 in 2012/2016). As school-aged children typically have high neighbourhood use (Blokland 2003; Karsten 2002), this may affect social segregation (see Table 13.1).

Figures 13.3, 13.4, 13.5, 13.6 and 13.7 map the distribution of the LQs of our indicators in both 2007 and 2016. In Fig. 13.3, LQs of unemployment for 2007 and 2016 reveal a very slight decrease in poverty concentration areas. The index went up in areas at the city borders far from the new centre such as the South-West, where we now observe less concentration of employed people without benefits and without poor children than in 2007. Other outskirts (as the North of Marzahn-Hellersdorf) desegregated somewhat. Formerly deprived inner-city neighbourhoods (parts of Kreuzberg and Neukölln) now have intermediate values, but pockets of high concentrations of unemployment remained. Land values and rents increased disproportionally here

\footnotetext{
${ }^{6}$ Foreigners and Germans born outside of Germany with second nationality, naturalized citizens, children of two foreign parents born in Germany since 2000. Changes in data-collection after 2014 ask for cautious interpretation of 2016 numbers (Nagel 2018: 59f).

${ }^{7}$ Egypt, Algeria, Bahrain, Djibouti, Iraq, Yemen, Jordan, Qatar, Comoros, Kuwait, Lebanon, Libya, Morocco, Mauritania, Oman, Saudi Arabia, Somalia, Sudan, Syria, Tunisia, United Arab Emirates. ${ }^{8}$ The IS (Apparicio et al. 2008: 1; Duncan and Duncan 1955) is defined by $I S=\frac{1}{2} \sum_{i=1}^{n}\left|\frac{x_{i}}{X}-\frac{t_{i}-x_{i}}{T-X}\right|$ and the most common one-group segregation measure. In this formula, $\mathrm{n}$ is the number of spatial units in the overall city (in our case: Berlin), $x_{i}$ is the total population of group $\mathrm{X}$ in spatial unit $\mathrm{i}$, $t_{i}$ the total population in spatial unit $\mathrm{i}, \mathrm{X}$ is the total population of $\mathrm{X}$ within the overall city. $\mathrm{T}$ is the total overall city population.
} 

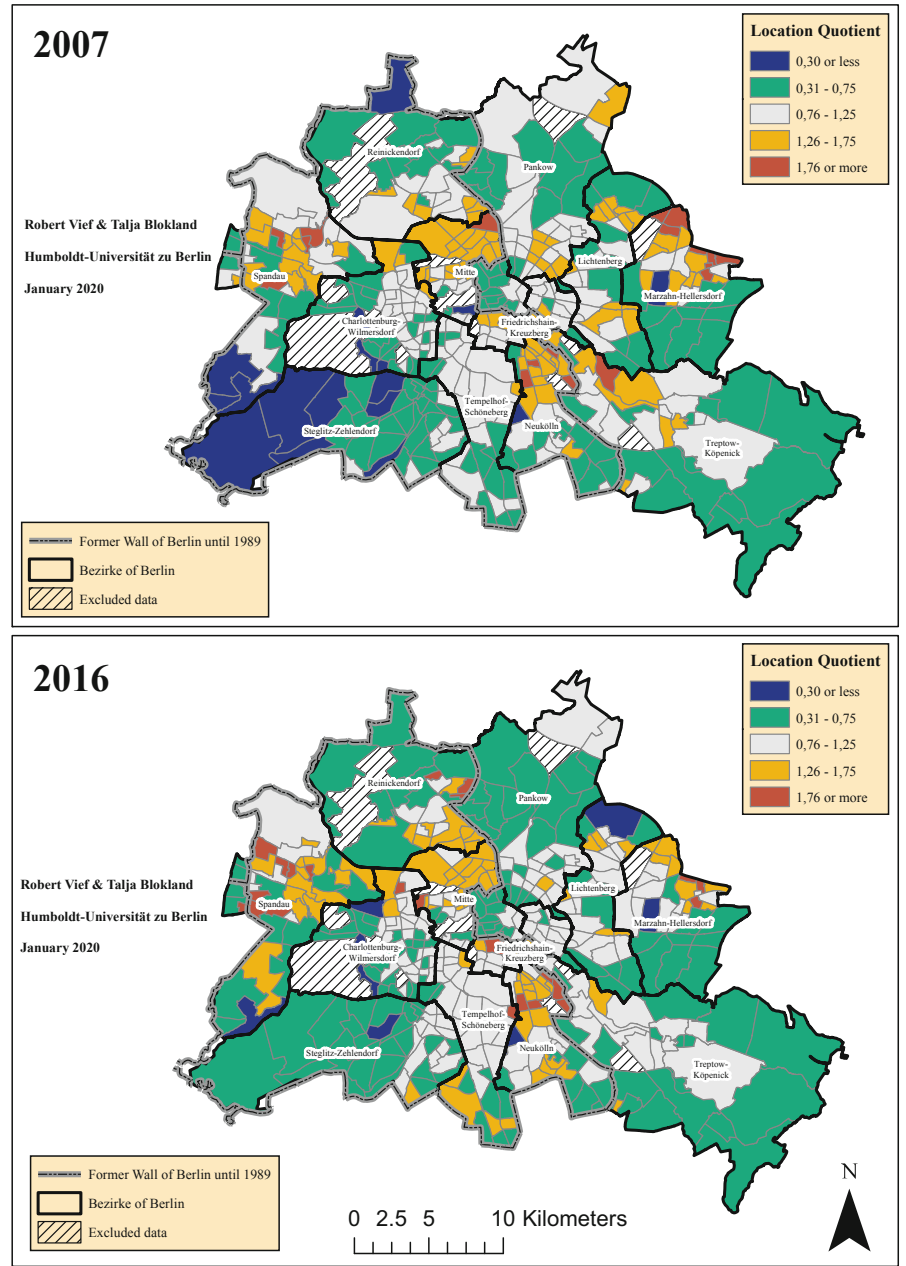

Fig. 13.3 Location quotients of unemployment (among 15- to 65-year-old population), in 2007 and 2016

(Holm 2013). Three factors may explain the invisibility of this gentrification. First, as a strategy to cope with the rent increase, people increasingly share apartments (Investitionsbank Berlin 2019). Second, highly mobile young people and global middle classes tend to prefer them. We have a division here between short-time working residents moving in and out quickly and a stable population for whom the new forms of the social mix have changed nothing for their unemployment rates and little for their children's poverty. Third, Kreuzberg and the North of Neukölln have inner-city modernist housing estates. New rental contracts see sharp rent increases (when new renters move in), but the moderate building structure and relative low level of amenities of these estates made their increase less than in other buildings, 
Table 13.1 Indices of segregation in Berlin

\begin{tabular}{|lcccc|c|}
\hline & $\mathbf{2 0 0 7}$ & $\mathbf{2 0 1 2}$ & $\mathbf{2 0 1 6}$ & Overall trend \\
\hline $\begin{array}{l}\text { Socio-economic indicators } \\
\text {-unemployed persons }\end{array}$ & 0.19 & 0.19 & 0.18 & $\begin{array}{l}\text { stable } \\
\text { stable }\end{array}$ \\
$\begin{array}{l}\text {-long-term unemployed persons } \\
\text {-non-unemployed persons }\end{array}$ & 0.20 & 0.19 & 0.19 & + slight increase \\
receiving state subsidies & 0.28 & 0.30 & 0.31 & +slight increase \\
-child poverty & 0.40 & 0.43 & 0.42 & & - strong decrease \\
$\begin{array}{l}\text { Ethnic indicators } \\
\text {-foreigners }\end{array}$ & 0.35 & 0.33 & 0.28 & - fair decrease \\
$\begin{array}{l}\text {-persons with migration } \\
\text { background }\end{array}$ & 0.34 & 0.33 & 0.30 & - strong decrease \\
-migration background: Turkey \\
and Arabic states
\end{tabular}

and residential stability remained high here. So far, this enabled residents to continue living there, as the German system of rent protection is relatively strong.

The LQ for child poverty for 2007 and 2016 (Fig. 13.4) indicates considerably stronger spatial segregation compared to unemployment, and concentrations in poverty, in contrast to all other indicators, slightly increased. Overall, the outskirts show a high concentration of non-poor children (Steglitz-Zehlendorf, parts of Marzahn-Hellersdorf, the north of Reinickendorf and the North-East of Pankow). These areas have the highest residential ownership rates. They have more singlefamily dwellings than average, making them preferred locations for affluent-enough families, reducing the likelihood of child poverty. Some of the spatial concentration of unemployment rates in inner-city areas results from the exceptionality of Berlin mentioned before. The current centre of the city has the redeveloped 'dead zone' (see Fig. 13.2) and renovated bourgeois housing ignored by the GDR. As luxury apartments are usually bought by people who work but are not necessarily preferred by parents, child poverty can remain stable while other indicators change.

The slight increase in segregation by child poverty after 2007 also produced new clusters in the outskirts where a large proportion of poor children lives, especially in Spandau's high-rise areas. Here, a closer analysis of suburbanization would be interesting. Located right at the city's edge, the disappearance of the Wall opened a hinterland for anyone who could afford to move, without an extreme increase in, for example, commuting time to workplaces since a regional train-connecting West Berlin with the hinterlands-returned for commuters in 1995. Selective migration from Spandau to Falkensee (noted above) may well help explain this poverty concentration. Kirchner (2009: 39) explained a high proportion of Falkensee's demographic growth as in-migration from Berlin. Spandau, in the 1920s already predominantly 

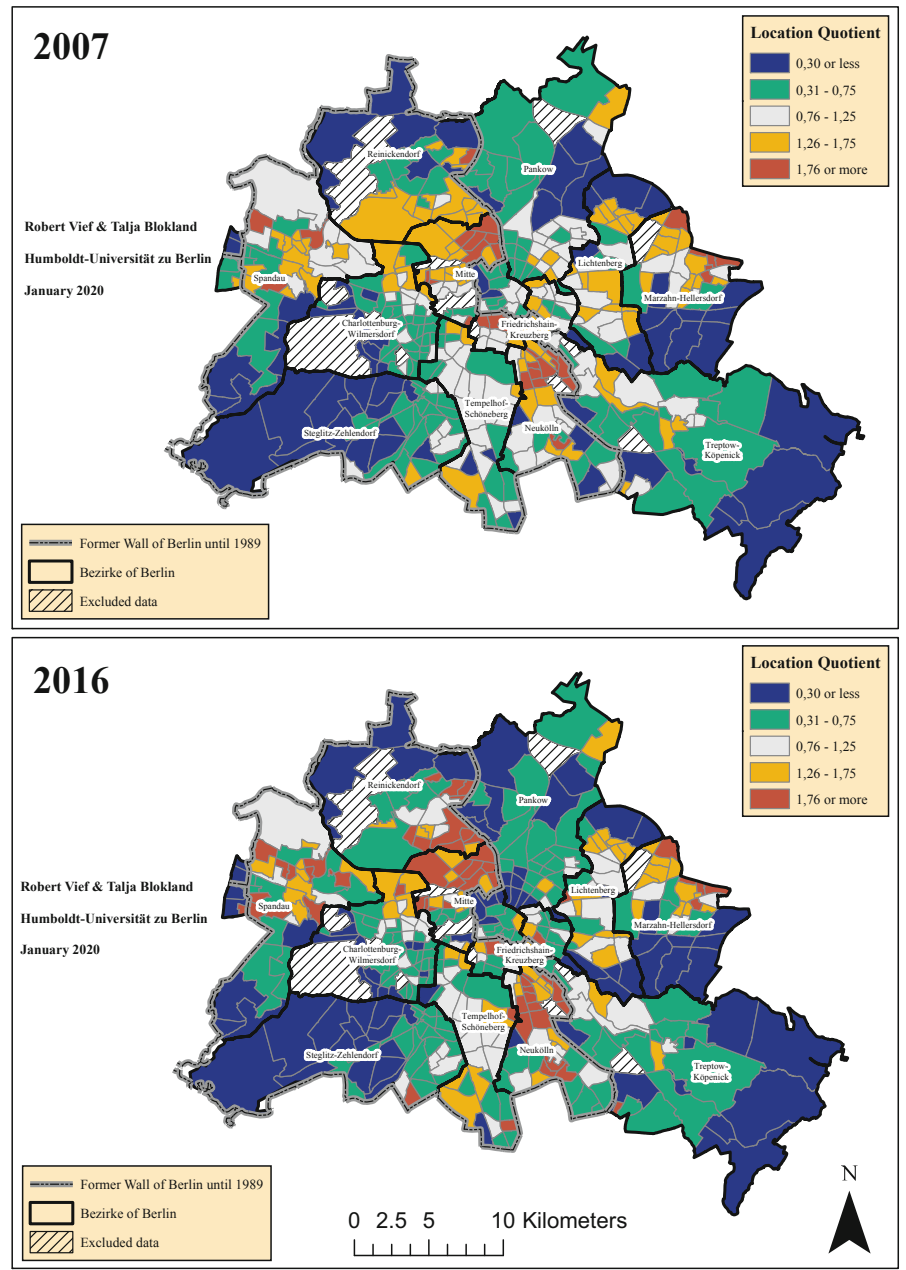

Fig. 13.4 Location quotients of child poverty (among 0-15 years-old population), in 2007 and 2016

working-class (Häußermann and Kapphan 2002: 45), was never a highly attractive city-part. Residents may have found better housing options in the direct geographical presence of their previous apartment after the Wende, an exceptional situation with Berlin's sudden opening up of hinterlands. If this is the case-and it begs further research-then social networks and even routines of daily activities may have changed very little. So even though residential segregation measured by child poverty has increased, we do not know what this means for social segregation.

Prenzlauer Berg (south of Bezirk Pankow), the gentrified neighbourhood with the highest birth rate for some years, where the stereotype of the latte-macchiato mother with an expensive stroller has been pasted to, saw its child poverty rate decrease. Other 

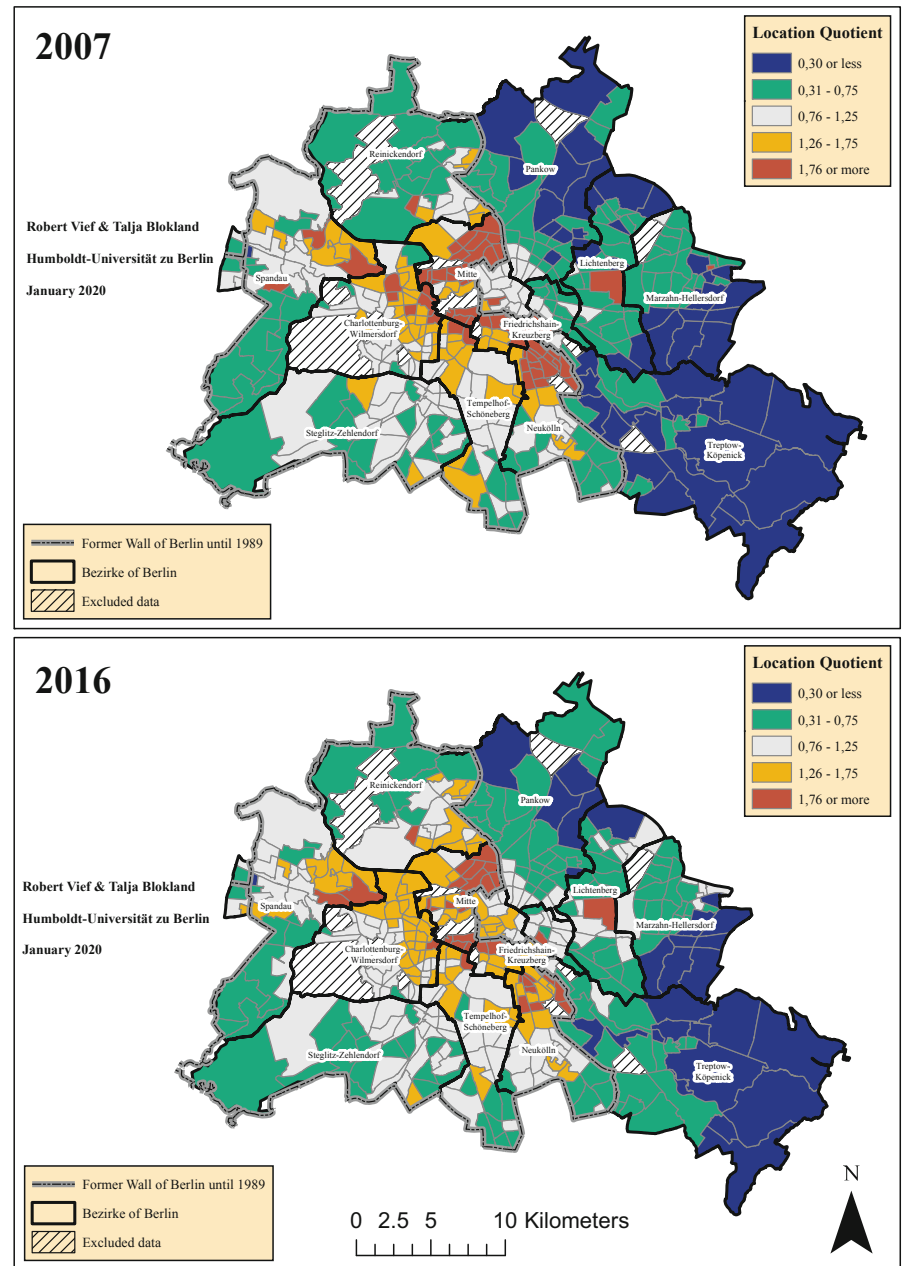

Fig. 13.5 Location quotients of Inhabitants with a migration background, in 2007 and 2016

areas (Charlottenburg-North, Wedding (Mitte), Reinickendorf's South) show much higher child poverty concentration than in 2007. This suggests that poor families increasingly disappear from areas where they lived before: either because they are no longer poor - the overall child poverty decrease suggests this plays some roleor because they moved elsewhere. Poor children may now also have become poor adults - we have no figures to measure this - and children who took their places may come from better-off families. Gentrification suggests that some previous poverty concentration hotspots now host wealthy young professionals and poor families.

When poor children live increasingly in areas with other poor children, does that matter in a city with Berlin's size and infrastructure? Are they able to leave their residential pockets and travel elsewhere in the city, for example? We connected the LQ 

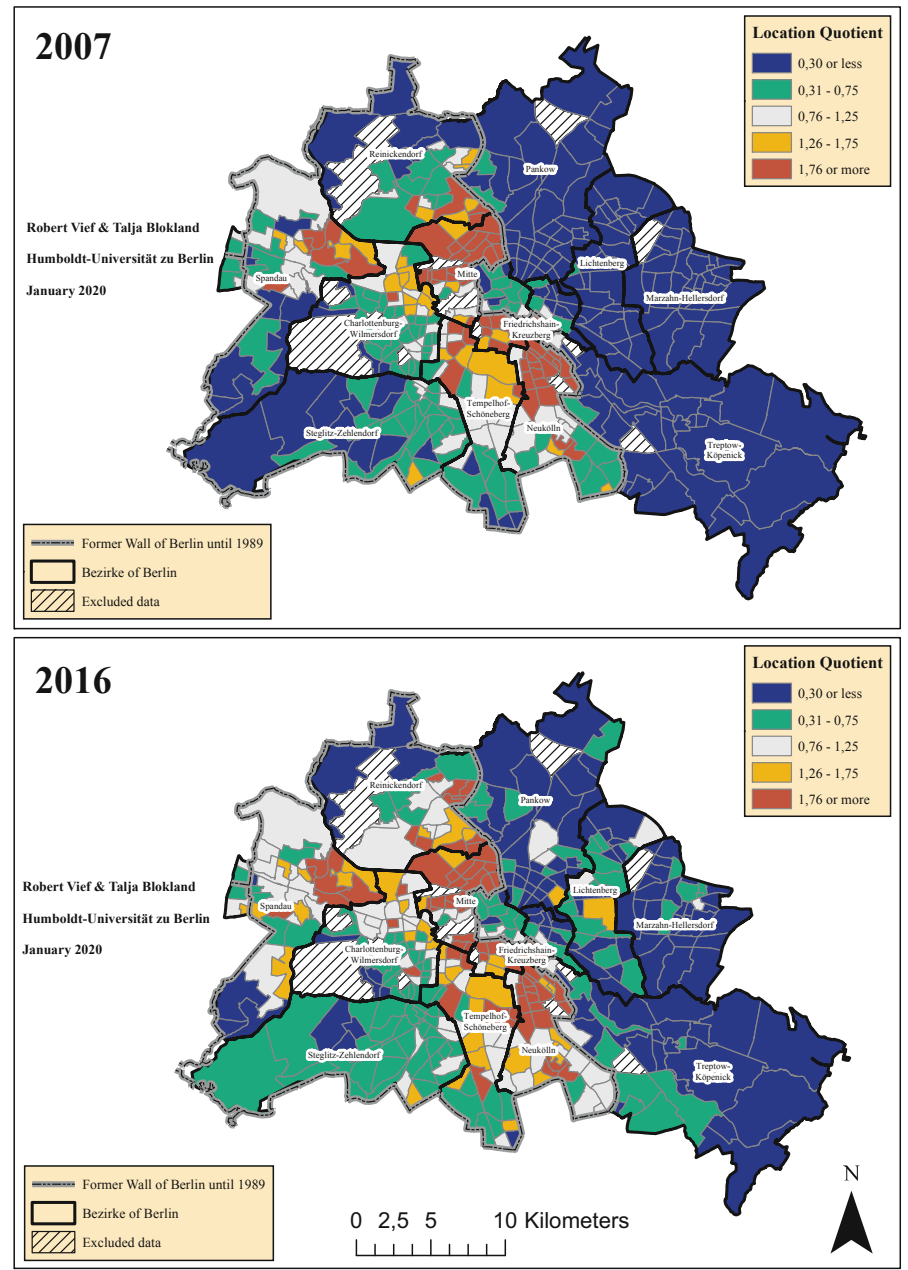

Fig. 13.6 Location quotients of Inhabitants with migration background from Turkey and Arabic States, in 2007 and 2016

data on child poverty segregation, unemployment rates and foreigners with indicators of distance from underground and regional train stations. Over time, concentration areas with few poor children had constant low access to public transport (Table 13.2). This affects their access to the city, but their parents mostly drive, and their access reflects low residential density. Poor children and (long term) unemployed residents now live in areas with worse public transport access than in 2007. As almost all post-reunification train lines re-openings were completed by 2006 and little changed between 2007 and 2016, poor families and unemployed residents thus moved (or had to move) to areas with poorer public transport access. 

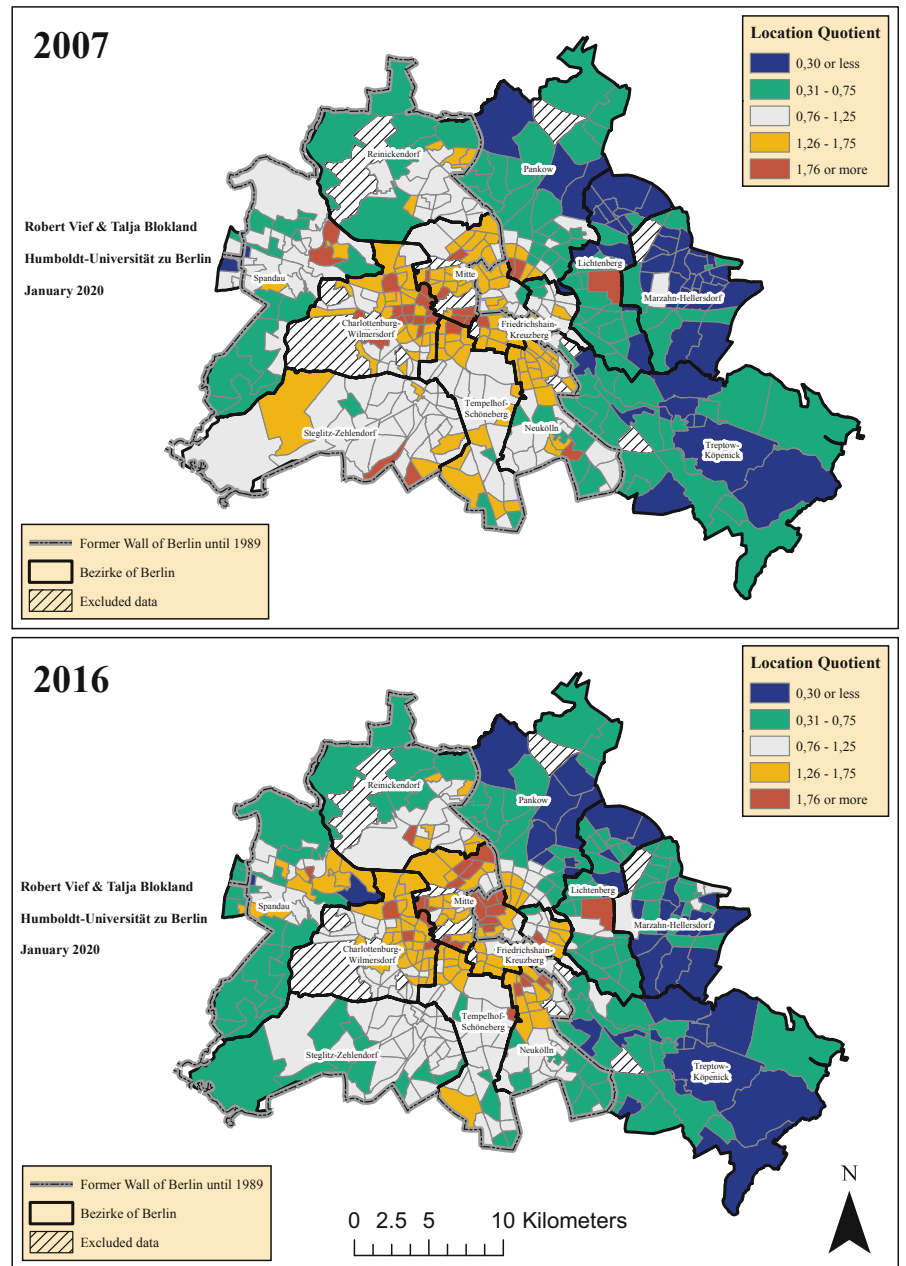

Fig. 13.7 Location quotients of Inhabitants with migration background from the European Union, in 2007 and 2016

\subsection{Segregation by Foreigner/Migration Background}

German cities always were more segregated by migration background than by socioeconomic groups, scholars claim (Friedrichs and Triemer 2009). In Berlin, both types of segregation approach each other. The IS for foreigners decreased from 0.35 in 2007 to 0.28 in 2016 (see Table 13.1), as did segregation by migration background (from 0.34 in 2007 to 0.30 in 2016).

The dispersion of segregation trends in Fig. 13.5 shows that foreigners and Germans with migration background continue to live more in West than East 
Table 13.2 Public transport access by the level of segregation and year

\begin{tabular}{|c|c|c|c|c|c|c|c|}
\hline \multicolumn{2}{|c|}{$\begin{array}{l}\text { Access to public transport by the } \\
\text { level of segregation }\end{array}$} & \multicolumn{6}{|c|}{$\begin{array}{l}\text { Average distance to next U-Bahn, S-Bahn or regional } \\
\text { train stop in meters }\end{array}$} \\
\hline \multirow[t]{2}{*}{ Indicator } & \multirow{2}{*}{$\begin{array}{l}\text { Year } \\
\text { Neighbourhoods } \\
\text { with LQ range }\end{array}$} & \multicolumn{3}{|l|}{2007} & \multicolumn{3}{|l|}{2016} \\
\hline & & Mean & SD & $\mathrm{N}$ & Mean & SD & $\mathrm{N}$ \\
\hline \multicolumn{8}{|c|}{ Socioeconomic indicators } \\
\hline \multicolumn{8}{|c|}{ - unemployment } \\
\hline & 0.3 or less & 1833 & 1620 & 19 & 1204 & 948 & 9 \\
\hline & $0.31-0.75$ & 1006 & 886 & 147 & 1090 & 1022 & 156 \\
\hline & $0.76-1.25$ & 770 & 751 & 152 & 733 & 673 & 162 \\
\hline & $1.26-1.75$ & 735 & 625 & 96 & 691 & 538 & 82 \\
\hline & 1.76 or more & 876 & 613 & 19 & 1214 & 1021 & 24 \\
\hline \multicolumn{8}{|c|}{ - long-term unemployment } \\
\hline & 0.3 or less & 1497 & 1360 & 39 & 1739 & 1619 & 39 \\
\hline & $0.31-0.75$ & 1019 & 941 & 135 & 929 & 809 & 127 \\
\hline & $0.76-1.25$ & 775 & 698 & 152 & 788 & 703 & 153 \\
\hline & 1.261 .75 & 622 & 564 & 77 & 689 & 545 & 85 \\
\hline & 1.76 or more & 1036 & 821 & 30 & 1183 & 929 & 29 \\
\hline \multicolumn{8}{|c|}{ - child poverty } \\
\hline & 0.3 or less & 1512 & 1322 & 75 & 1197 & 1244 & 86 \\
\hline & $0.31-0.75$ & 851 & 799 & 125 & 849 & 705 & 145 \\
\hline & $0.76-1.25$ & 864 & 753 & 101 & 836 & 764 & 70 \\
\hline & $1.26-1.75$ & 731 & 572 & 97 & 774 & 549 & 70 \\
\hline & 1.76 or more & 608 & 595 & 35 & 805 & 748 & 62 \\
\hline
\end{tabular}

Berlin. ${ }^{9}$ Between 2007-2016, some clusters of foreigners remained. Others acquired a more balanced LQ (such as Kreuzberg). More foreigners now also live in Eastern areas. Foreigners is a broad concept. For example, in gentrifying Neukölln and Kreuzberg, 'foreigners' include more and more EU and US citizens. Over 10,000 of the 13,263 residents who moved to Neukölln between 2011-2017 carry these passports. People from 'Muslim countries' went up by only 2,600 (Amt für Statistik Berlin-Brandenburg 2012, 2017b). Our analysis of segregation by migration background from Turkey/Arabic States underlines this aspect (Fig. 13.6). The IS for this group dropped sharply from 0.51 to 0.41 in nine years. More persons from this group left formerly very segregated inner-city pockets (such as Wedding, Kreuzberg or Neukölln-North). The overall segregation for EU-citizens is moderate and stable (around 0.23), but the development of their segregation shifts to inner-city areas (Fig. 13.7).

\footnotetext{
${ }^{9}$ Except for one in Lichtenberg, with Vietnamese residents, an increase of Bulgarians and other Eastern Europeans and a refugee center.
} 


\subsection{How Does Segregation Matter?}

As Marcuse (1993: 357 in Hamnett 2003: 167) argued 25 years ago, divided cities are nothing new. From ancient Athens and Rome onwards, the poor have lived away from the rich: 'at least from the outset of the industrial revolution, cities have been divided in ways that are quite familiar to us' (ibid.). So how does segregation matter?

Statistics of where people sleep matters when we assume that people do not leave their concentration areas and residents have access to amenities, networks or other resources only through their residential location. This assumption is questionable (Blokland and van Eijk 2010). A mixed environment can be social wallpaper for the better-off (Butler 2003) without them ever building network ties with people in lower social, economic or cultural positions. Curley (2008) showed that people who moved from poverty pockets to mixed areas benefitted because their resources were no longer drained, not because new social capital emerged. Kronauer (2002) suggested that much depends on life conditions: single mothers found best support infrastructures in apartment blocks on the outskirts, single unemployed persons benefitted most from inner-city resources. So, segregation effects on life chances are multi-faceted and dynamic, even within one life-trajectory.

Besides networks, social capital and cultural interpretations, scholars may want to focus much more on urban infrastructure, including its precise workings for access to resources. Social segregation, the degree to which people conduct their role repertories (Blokland 2003; Hannerz 1980) in relative isolation or interaction with people with a different class or racial/ethnic position than theirs, emerges through these workings.

Berlin is a well-connected city; public transport is affordable and even free for school children. However, segregated poverty, as we saw before, coincides now with less easy transport access. When moving around the city becomes more difficult for those who are most disadvantaged, it starts to matter where things are located. Resource access is central to how segregation matters, especially for resources through which social positions are reproduced: resources for raising kids. Four examples, drawing on students' work at Humboldt, support this claim.

First, this work suggests a congruence of socioeconomic segregation and distribution of certain child-oriented resources. We mapped elementary schools, kindergarten and praxis for speech- and ergo-therapy. The choice of kindergarten types is smaller in high unemployment areas (Fritz 2013). Elementary school access is equal, but high unemployment areas have fewer schools with special profiles. Other indicators (teacher absence, computers in school, teacher/student ratio) show no systematic pattern (Zwirner 2013). People living in affluent areas have a higher chance of having therapists nearby. As high child poverty shifted to locations with worse public transport, this can point to a difference in life chances.

Second, school segregation does not require residential segregation. Berlin's elementary school zoning laws should create schools with the same composition as their catchment zone. Parents cannot simply send children elsewhere. In practice, parents differ in their possibilities to do so (Blokland and Große Löscher 2016). 
Especially in not segregated neighbourhoods, schools are more segregated than they should be for the residential composition (Vief 2018). As strongest schoolneighbourhood segregation gaps occur in mixed settings, residential mix does not necessarily create a social mix in important institutions.

Third, as children's actual neighbourhood use tends to be high (Blokland 2003), the interplay of family and neighbourhood works differently in areas different in poverty concentration. In a middle-class pocket in Lichterfelde (Steglitz-Zehlendorf) and an owner-occupied development in Kreuzberg, qualitative interviews with parents taught us that both lived with people with similar orientations on dominant parenting ideas. Interviewees showed little awareness of the rest of the city and a localness in their use of facilities and non-family networks. The neighbourhood worked as village — or exclusive island. The interviewees did not intentionally avoid mixing with people unlike themselves. But even in a middle-class enclave in a hyper-diverse district, the parents were so oriented on organizing the best resources for their children that it never occurred to them that their practices of secluding (Giustozzi et al. 2016) excluded others (Blokland and Große Löscher 2016: 81-82). Giustozzi concluded (2016: 100): 'Effectively (...) these mothers avoided routes through the city - also shown in their preference for cars over public transport-for fluid encounters (...) with residents unlike themselves. (...) Segregation, then, was actively enhanced and reified by residential choices and everyday practices of these mothers.

Fourthly, social processes affect the relative absence of migrants and foreigners in East Berlin. The long length of residence in some of these areas suggest that few places became vacant, and residential mobility is low there. Häußermann and Kapphan (2002) claimed that foreigners chose not to move to the East because of Neonazis. That certain Eastern parts were 'spaces of fear' for migrants had since become a claim frequently used geographically to address the right-wing extremism and related fears of their potential victims, non-White Germans and immigrants (Lewek 2016: 37), producing imaginaries accordingly. The reproduction of the imagery of racism is a problem of 'the East' locates it away from the core of the city and its proper 'Western' democratic qualities, but the evidence is weak. When we asked people with a Sub-Saharan migration background to draw on a Berlin map where they went or did not go, they excluded Eastern Berlin areas. In the early 2000s, racist violence tended to be stronger in the East of the city. Some nationalist, racist meeting venues moved from Eastern areas to the region around Berlin (Shoshan 2016), but the extreme right-wing political party AFD holds office in Köpenick and focusses electoral propaganda on Treptow-Köpenick and Marzahn-Hellersdorf, making racism visible.

That segregation occurs from migrant choices not to move to East Berlin out of a fear of racism (Häußermann and Kapphan 2002) is tentative but a common narrative. This narrative, Lewek (2016) argued, helped the city marketing itself as diverse, hip and tolerant. By effectively spatializing racism in areas with low tourist attractivity anyway, where it was constructed as a problem of the particular backwardness of a particular part of Berlins population, the rest of the city could be marketed as welcoming cosmopolitan. The imagery may have worked: in the last 
20 years, migration background only increased slowly and slightly in these areas, although collective performances of right-wing extremists today are less spatially concentrated in the Eastern part of Berlin (ibid.: 248). Most reported racist incidents now happen in Neukölln and the new Mitte, in contrast to the early 2000s. ${ }^{10}$

In another study, lower-class migrant youth reported avoidance of areas where they felt unwelcome (Blokland and Šerbedžija 2018). Young men with Arab and Turkish roots in two Kreuzberg estates curbed their city use to avoid racist encounters. Diego expressed fear in Marzahn: 'five or six Germans who will stand next to you will think: Come on, there is a foreigner, he is going to get beaten'. Another youth had been 'stupidly talked to' by a 'Granny' who scolded that 'you foreigners' made her Bezirk, Hellersdorf, kaputt. Their local comfort zone (Blokland and Nast 2014) was a response to experiences of discomfort elsewhere, interviewee Serdar suggested:

\section{[...] [what causes that] you don't like to go much into other Bezirke?}

'You can't really put that to words, because I had a job training once (...) in Spandau (...) I felt not at all, zero well there, for real. Because you notice like, they look at you differently. (...) we, apparently, the foreigners have something against the Germans, they treat them badly and so on (.) But really (...) the ones that label us that way, these are mostly the people, that live according to the old (...) mentalities, like so GDR, like some of them still have that in their heads. And you see it very well, one recognizes it clearly (...) Even though you're born here, you have no difference form them, only that in your roots you happen to be Turkish (..) they say (...) you aren't a German and so on (...) they want to be the only Germans. (Blokland and Šerbedžija 2018: 35)

Serdar interpreted his Spandau experience through the common lens of East Berlin as a container of racists. Spandau, however, was always West-Berlin. These experiences were not at all located in the East only. Two young migrant women felt discomfort in all Bezirke with few people with migration background: exactly the locations where mothers quoted above felt so comfortable as they did not 'have to protect' their children, living in a 'village'. Here these women felt 'uncomfortable' and 'as exclusion, to be honest':

When one gets to places where there are few migrants (...) it is always quite glaring (krass). In Zehlendorf (...), I was there (...) because my brother-in-law was in the hospital (...) I walked around with my nephew (...) and two minutes down the street, there is a lamppost, and it has sticker on it, 'Islamist out', 'Migrants out', 'Nafros go home' - so really krass. And then I walked around there thinking, shit, when I would be wearing a headscarf here, what would happen to me? (...) You get a look, I don't know, it is always this krasse feeling, then I think, I belong here too, what are you looking at me like that for?'.

The closure of the city goes further than that when migrant youth experience that 'normal' behaviour is demonized. Emre reportedly travelled to his internship but was late, so ran from his train over the platform at a main railway station. He was stopped by police or security. They asked his ID, then to open his bag, then questioned him if he had stolen something — all taking 10 min of Emre's time, making him arrive late at his workplace: 'they did not believe me at first because I was out of breath, because I ran, they thought I must be fleeing'. Not everyone running at a station is

\footnotetext{
${ }^{10}$ See for example: Register Berlin (2019); Senatsverwaltung für Inneres und Sport (2007).
} 
stopped. Emre sensed that. For these youngsters, the everyday experience of being undesired and put under general suspicion and policing was even stronger outside their neighbourhood. They limited their use of the city for stories told and experiences made with subtle and direct racism. To these experiences, East/West divisions do not apply_but discursively impact imaginaries.

\subsection{Conclusion}

Berlin's residential segregation is moderate to low, and not univocally increasing, especially not for people with migration background. Socioeconomic inequality by income was stable between 2007 and 2016 but could only be measured at the Bezirke level. On a smaller spatial scale, segregation for the working-age population was stable, but slightly increased for poor children. Contrary to public perception, segregation by foreigners/migration background decreased, especially for inhabitants with roots from Turkey and 'Muslim' states. Some pockets of poverty concentration shifted from (well-connected) inner-city areas to (worse-connected) outskirts.

Residential segregation does not necessarily mean social segregation, no more than that, residential mix means social mix. Statistical segregation in terms of where people fitting certain categories spend the nights may have little connection to their actual city use, although neighbourhood use may correlate with our role repertoires, and role repertories change over time (Blokland 2003). We suggested that social segregation, more than residential segregation, is what divides a city. A strong role in how Berliners use the city play, firstly, subtle forms of racism-a sign on a wall, a remark made loudly, a seat changed on the bus to not come near 'a migrant'. Secondly, the middle class, especially German and European, may engage in secluding practices when organizing their daily lives, securing the best resources for their own-excluding others as a consequence.

So social and residential segregation must be analytically separated, especially for understanding (the reproduction of) urban inequalities. We suggest that social segregation in Berlin is a more important theme than the statistical question of who sleeps where. Social segregation of the use of urban places and institutions in the city may influence the reproduction of disadvantage across groups and possibly generations.

\section{References}

Amt für Statistik Berlin-Brandenburg (2012) Statistischer Bericht A I 5 - hj 2/11, Berlin. https:// www.statistik-berlin-brandenburg.de/Publikationen/Stat_Berichte/2012/SB_A01-05-00_201 1h02_BE.pdf. Accessed 15 Feb 2020

Amt für Statistik Berlin-Brandenburg (2017a) Regionaler Sozialbericht Berlin und Brandenburg 2017, Potsdam. https://www.statistik-berlin-brandenburg.de/produkte/pdf/SP_Sozialbericht000-000_DE_2017_BBB.pdf. Accessed 15 Feb 2020 
Amt für Statistik Berlin-Brandenburg (2017b) Statistischer Bericht A I 5 - hj 1/17, Berlin. https://www.statistik-berlin-brandenburg.de/publikationen/stat_berichte/2017/SB_A01-05-00_ 2017h01_BE.pdf. Accessed 15 Feb 2020

Amt für Statistik Berlin-Brandenburg (2019) Statistischer Bericht: Einwohnerinnen und Einwohner im Land Berlin am 31. Dezember 2018, Potsdam. https://www.statistik-berlin-brandenburg.de/ publikationen/stat_berichte/2019/SB_A01-05-00_2018h02_BE.pdf. Accessed 15 Feb 2020

Apparicio P, Martori JC, Pearson AL, Fournier É, Apparicio D (2013) An open-source software for calculating indices of urban residential segregation. Soc Sc Comput Rev 32:117-128

Apparicio P, Petkevitch V, Charron M (2008) Segregation analyzer: a C\#. Net application for calculating residential segregation indices. Cybergeo 414:1-27

Beran F, Czarnetzki F, Nuissl H (2015) Von der Suburbanisierung zur Reurbanisierung in Berlin? Standort 39:62-68

Bernt M, Grell B, Holm A (2013) Introduction. In: Bernt M, Grell B, Holm A (eds) The Berlin reader. Transcript, Bielefeld, pp 11-24

Beyer W, Schulz M (2001) Berlin—Suburbanisierung auf Sparflamme!? In: Brake K, Dangschat JS, Herfert G (eds) Suburbanisierung in Deutschland: Aktuelle Tendenzen. Leske \& Budrich, Opladen, pp 123-150

Blokland T (2003) Urban bonds. Polity Press, Cambridge

Blokland T, Große Löscher G (2016) Cheating the system to get the best for one's kids: middle class practices and racist marginalization. In: Blokland T, Giustozzi C, Krüger D, Schilling H (eds) Creating the unequal city. Ashgate, Farnam, pp 71-83

Blokland T, Nast J (2014) From public familiarity to comfort zone. IJURR 38:1142-1159

Blokland T, Šerbedžija V (2018) Gewohnt ist nicht normal: Jugendalltag in zwei Kreuzberger Kiezen. Logos-Verlag, Berlin

Blokland T, van Eijk G (2010) Do people who like diversity practice diversity in neighbourhood life? JEMS 36:313-332

Bluth F (2004) Stadt - Umland - Wanderung im Raum Berlin. Berliner Statistik. Monatsschrift 94-99

Bodnar J, Molnar V (2010) Reconfiguring private and public. Urban Stud 47:789-812

Bömermann H, Jahn S, Nelius K (2006) Lebensweltlich orientierte Räume im Regionalen Bezugssystem. https://www.stadtentwicklung.berlin.de/planen/basisdaten_stadtentwicklung/ lor/download/BerlinerStatistik0608.pdf. Accessed 15 Feb 2020

Butler T (2003) Living in the bubble: gentrification and its 'others' in North London. Urban Stud 40:2469-2486

Curley AM (2008) A new place, a new network?: social capital effects of residential relocation for poor women. In: Blokland T, Savage M (eds) Networked urbanism. Ashgate, Farnam, pp 85-104

Dahn D (1987) Prenzlauer Berg-Tour. Mitteldeutscher Verlag, Halle

Duncan OD, Duncan B (1955) A Methodological analysis of segregation indexes. ASR 20:210

Eisenmenger M, Loos C, Sedmihradsky D (2014) Erwerbstätigkeit in Deutschland - Ergebnisse des Zensus 2011. Wirtschaft und Statistik 544-560

Friedrichs J, Triemer S (2009) Gespaltene Städte?: Soziale und ethnische Segregation in deutschen Großstädten. VS Verlag für Sozialwissenschaften, Wiesbaden

Fritz D (2013) Kindertagesbetreuung als Nachbarschaftsressource und die Reproduktion von Ungleichheit. Unpublished paper, HU Berlin

Gathmann C, Keller N, Monscheuer O, Straubhaar T, Schäfer H, Zimmermann KF, Brücker H (2014) Zuwanderung nach Deutschland-Problem und Chance für den Arbeitsmarkt. Wirtschaftsdienst 94:159-179

Giustozzi C (2016) In the interest of the child: gendered practices of middle class mothers. In: Blokland T, Giustozzi C, Krüger D, Schilling H (eds) Creating the unequal city. Ashgate, Farnam, pp 85-106

Giustozzi C et al (2016) Secluding: middle class segregation in schools and neighborhoods. In: Blokland T, Giustozzi C, Krüger D, Schilling H (eds) Creating the unequal city. Ashgate, Farnam, pp 53-70

Gornig M et al (2013) Wirtschaftsentwicklung in Berlin: Szenario 2030. DIW Berlin, vol 77 
Gould M (1999) Race and theory: culture, poverty, and adaptation to discrimination in Wilson and Ogbu. Sociol Theory 17:171-200

Grabka MM, Goebel J, Liebig S (2019) Wiederanstieg der Einkommensungleichheit - aber auch deutlich steigende Realeinkommen. DIW Wochenbericht 344-353

Hamnett C (2003) Unequal city: London in the global arena. Routledge, London

Hannerz U (1980) Exploring the city. Columbia UP, New York

Harvey D (1978) The urban process under capitalism: a framework for analysis. IJURR 2:101-131

Häußermann H, Kapphan A (2002) Berlin. Von der geteilten zur gespaltenen Stadt? VS Verlag für Sozialwissenschaften, Wiesbaden

Häußermann H, Kapphan A (2004) Berlin: Ausgrenzungsprozesse in einer europäischen Stadt. In: Häußermann H, Kronauer M, Siebel W (eds) An den Rändern der Städte: Armut und Ausgrenzung. Suhrkamp, Frankfurt/Main, pp 203-234

Heckel C, von der Heyde C (2015) Anmerkungen zum Zensus 2011 aus Sicht der Markt- und Sozialforschung. AStA Wirtschafts- Und Sozialstatistisches Archiv 9:251-268

Helbig M, Jähnen S (2018) Wie brüchig ist die soziale Architektur unserer Städte? Trends und Analysen der Segregation in 74 deutschen Städten. WZB discussion paper, Berlin. https://www. econstor.eu/bitstream/10419/179001/1/p18-001.pdf. Accessed 15 Feb 2020

Herrnstein RJ, Murray C (1996) The bell curve: intelligence and class structure in American life. Simon \& Schuster, New York

Holm A (2013) Berlin's gentrification mainstream. In: Bernt M, Grell B, Holm A (eds) The Berlin reader. Transcript, Bielefeld, pp 171-189

Holzer H (1991) The spatial mismatch hypothesis: what has the evidence shown? Urban Stud 28:105-122

Investitionsbank Berlin (2019) IBB Wohnungsmarktbericht 2018. https://www.ibb.de/media/dok umente/publikationen/berliner-wohnungsmarkt/wohnungsmarktbericht/ibb_wohnungsmarktbe richt_2018.pdf. Accessed 15 Feb 2020

Karsten L (2002) Mapping childhood in Amsterdam: the spatial and social construction of children's domains in the city. TESG 93:231-241

Kemper F-J (1998a) Residential segregation and housing in Berlin: changes since unification. GeoJournal 46:17-28

Kemper F-J (1998b) Restructuring of housing and ethnic segregation: recent developments in Berlin. Urban Stud 35:1765-1789

Kirchner F (2009) Soziale Integration in Gemeinden rund um Berlin - Netzwerke Alteingesessener und Zugezogener in der Stadt Falkensee. Master's thesis, HU Berlin

Kronauer M (2002) Exklusion: Die Gefährdung des Sozialen im hoch entwickelten Kapitalismus. Campus, Frankfurt/Main

Lewek M (2016) Spaces of fear and their exclusionary consequences. In: Blokland T, Giustozzi C, Krüger D, Schilling H (eds) Creating the unequal city. Ashgate, Farnam, pp 31-52

Marcuse P (1993) What's so new about divided cities? IJURR 17:355-365

Marques E (2012) Opportunities and deprivation in the urban South. Ashgate, Farnham

Matthiesen U, Nuissl H (2002) Phasen der Suburbanisierung seit 1989. In: Matthiesen U (ed) An den Rändern der Deutschen Hauptstadt. Leske + Budrich, Opladen, pp 79-92

Nagel H (2018) Monitoring Soziale Stadtentwicklung Berlin: Erläuterungen zu den Indikatoren und Indizes zum MSS 2017 - "Indikatorenblätter", Berlin. https://www.stadtentwicklung.ber lin.de/planen/basisdaten_stadtentwicklung/monitoring/download/indikatoren/MSS2017Indik atorenblaetter_Fortschreibung.pdf. Accessed 15 Feb 2020

Register Berlin (2019) Auswertung 2018 der Berliner Register zur Erfassung rechter, rassistischer, antisemitischer, LGBTIQ*-feindlicher und anderer diskriminierender Vorfälle, Berlin. https:// www.berliner-register.de/sites/default/files/Registerauswertung_Berlin_2018.pdf

Sampson RJ (2012) Great American city: Chicago and the enduring neighborhood effect. The University of Chicago Press, Chicago, London

Sampson RJ, Raudenbush SW, Earls F (1997) Neighborhoods and violent crime. Science 277:918-924 
Senatsverwaltung für Inneres und Sport (2007) Rechte Gewalt in Berlin: 2003 bis 2006. im Fokus, Berlin. https://www.verfassungsschutz.de/de/oeffentlichkeitsarbeit/publikationen/pb-rechtsext remismus/publikationen-landesbehoerden-rechtsextremismus/broschuere-be-2007-11-rechtegewalt-in-berlin-2003-2006. Accessed 15 Feb 2020

Shoshan N (2016) The management of hate. Princeton, Princeton UP

Small ML (2009) Unanticipated gains: origins of network inequality in everyday life. Oxford UP, New York

de Souza Briggs X (1997) Moving up versus moving out: neighbourhood effects in housing mobility programs. Hous Policy Debate 8:195-234

Statistische Ämter des Bundes und der Länder (2015) Zensus 2011. Methoden und Verfahren, Wiesbaden. https://www.zensus2011.de/SharedDocs/Downloads/DE/Publikationen/Aufsaetze_Arc hiv/2015_06_MethodenUndVerfahren.pdf?_blob=publicationFile\&v=6. Accessed 15 Feb 2020

Vief R (2018) 'Stacking the odds': the intersection between neighborhood and school segregation. A comparison between New York and Berlin. Master's thesis, HU Berlin

Wacquant LJD (2008) Urban outcasts: a comparative sociology of advanced marginality. Polity Press, Cambridge

Wrigley N (2002) Food Deserts' in British cities. Urban Stud 39:2029-2040

Zwirner L (2013) Inwiefern besteht eine Korrelation zwischen Wohngebiet und Schulqualität? Unpublished paper, HU Berlin

Open Access This chapter is licensed under the terms of the Creative Commons Attribution 4.0 International License (http://creativecommons.org/licenses/by/4.0/), which permits use, sharing, adaptation, distribution and reproduction in any medium or format, as long as you give appropriate credit to the original author(s) and the source, provide a link to the Creative Commons license and indicate if changes were made.

The images or other third party material in this chapter are included in the chapter's Creative Commons license, unless indicated otherwise in a credit line to the material. If material is not included in the chapter's Creative Commons license and your intended use is not permitted by statutory regulation or exceeds the permitted use, you will need to obtain permission directly from the copyright holder.

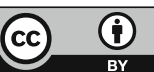

